\title{
Anmeldelser
}

Tips om medisinsk litteratur, andre bøker, filmer og elektroniske medier som bør anmeldes, sendes tidsskriftet@legeforeningen.no

\section{Innsiktsfullt om selvskading}

Moe A, Ribe K.

Selvskadingens dynamikk

178 s, ill. Oslo: Universitetsforlaget, 2007.

Pris NOK 299

ISBN 978-82-15-01133-2

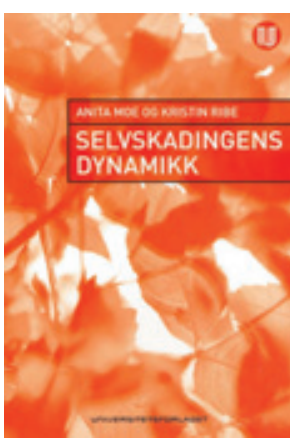

«Å sy deg er lett. $\AA$ hjelpe deg er vanskelig.» Legen som uttalte dette, tok saken på kornet - den vanskelige utfordringen det kan være å gi effektiv hjelp til personer som skader seg selv med vilje. Pasienten i det aktuelle tilfellet var Kristin Ribe, en av de to forfatterne av Selvskadingens dynamikk, en bok som henvender seg til både hjelpere og brukere med tanke på behandlingstjenester for selvskadere. Ribe har omfattende og langvarige egenerfaringer med selvskading. Anita Moe, bokens andre forfatter, er psykolog og forsker med erfaring fra behandling særlig av kvinner med selvskadingsproblematikk. Moe og Ribe har i et dristig og kreativt grep valgt å forene sine krefter og ulike perspektiver for å gi leserne et bedre grunnlag for refleksjon og innsikt i dynamikken som ligger under selvskading. I dette har de lykkes.

Her finner vi både brukeren Kristin Ribes sterkt personlige og hudløst ærlige skildringer av tanker, følelser og reaksjoner relatert til selvskading. Hun klarer det så godt at $\mathrm{i}$ alle fall klinikerne blant leserne lett vil få kontakt med egne følelsesmessige reaksjoner i møte med selvskaderen. Klinikeren Anita Moe beskriver utviklingspsykologiske aspekter ved selvskadingen og drøfter ulike stadier i den selvskadende prosessen på en innsiktsfull måte.

Temaet er krevende og forfatterne pretenderer ikke å gi noen fasitgyldige svar. På enkelte punkter trekker de riktignok en del konklusjoner som det ikke nødvendigvis er enighet om i fagfeltet. Det gjelder blant annet den skarpe grensedragningen de foretar mellom selvskading og suicidalitet. Her fortoner nok virkeligheten for store grupper av pasienter seg meget mer komplisert enn det boken kan gi inntrykk av. Dette svekker likevel ikke inntrykket av at begge forfattere har inngående kunnskap om sitt stoff og har evne til å formidle det $\mathrm{i}$ et godt språk og med innlevelse og varme. For noen vil denne boken fortone seg som noe usystematisk, løs i oppbygningen og med en tendens til gjentakelser. Slik sett egner den seg ikke så godt som læreverk. Men som grunnlag for refleksjon og diskusjon vil den egne seg utmerket for store grupper av helsepersonell som møter pasienter som skader seg selv med vilje.

\section{Lars Mehlum}

Nasjonalt senter for selvmordsforskning og-forebygging

Institutt for psykiatri

Universitetet i Oslo

\section{Atferdsterapi og selvmordstruede tenåringer}

Miller AL, Rathus JH, Linehan MM.

Dialectical behavior therapy with suicidal adolescents

346 s, tab, ill. New York, NY: Guilford Press, 2007. Pris USD 42

ISBN 978-1-59385-383-9

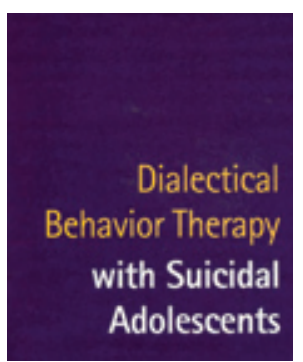

Den amerikanske psykologiprofessoren Marsha M. Linehan, som er medforfatter av denne boken, utviklet behandlingsformen dialektisk atferdsterapi (dialectical behavior therapy, DBT) og

beskrev metoden bl.a. i to bøker i 1993.

Disse er nå klassikere og bør leses av alle som vil ha en mer grundig innføring i denne behandlingsformen $(1,2)$. Dialektisk atferdsterapi ble opprinnelig laget for å behandle unge kvinner med emosjonelt ustabil personlighetsforstyrrelse og suicidalproblematikk. Integrert i terapiformen er kunnskap fra atferdsterapi, kognitiv terapi og østlig zenfilosofi. Nå tilbys formell utdanning i dialektisk atferdsterapi i Norge i et samarbeid mellom Nasjonalt senter for selvmordsforskning og -forebygging ved Universitetet i Oslo og Regionsenter for barn og unges psykiske helse, Helseregion Sør-Øst.

Når hele pasientgruppen er tenåringer med ustabile personlighetstrekk og suicidalitetsproblematikk, har forfatterne erfart at det er hensiktsmessig med tilpasninger av den opprinnelige behandlingsmetodikken, noe som er utgangspunktet for at de har skrevet denne boken. Eksempler på tilpasninger er inkludering av foreldrene i den psykoedukative ferdighetstreningsgruppen, endring av temaer og treningsoppgaver for ferdighetsopplæringen slik at disse er spesielt relevante for tenåringer og kortere behandlingsvarighet med 16 ukers behandling i stedet for ett år. Målgruppen er terapeuter som bruker dialektisk atferdsterapi og som allerede jobber med suicidale tenåringer eller vurderer å starte med dette. Forfatterne håper også å introdusere behandlingsformen til klinikere som ikke er kjent med den fra før. Boken inneholder tabeller og sjekklister som kan brukes til å planlegge behandlingen. Det er vedlagt praktisk tilrettelagt informasjon til bruk i den psykoedukative ferdighetstreningen, referanseliste og indeks.

Dialektisk atferdsterapi beskrives generelt og tilpasninger ved behandling av tenåringer beskrives spesielt. I tillegg til den grundige teoretiske oversikten over området, gir boken også en detaljert praktisk innføring i gjennomføring av behandlingen. Man veiledes trinn for trinn fra oppstart med teknikker for motivering av tenåringen via intervensjoner underveis i individualterapien, gjennomgang av temaer i den psykoedukative ferdighetstreningsgruppen og intervensjoner i forhold til foreldrene, for å nevne noe. Det gis mange instruktive, praktiske eksempler. Jeg vil anbefale denne innholdsrike boken til terapeuter innen psykisk helsevern som vil hjelpe tenåringer som sliter med personlighetstrekk forenlig med emosjonelt ustabil personlighetsforstyrrelse.

\section{Anne Irene Jensen}

Follo distriktspsykiatriske senter Oslo universitetssykehus, Aker

\section{Litteratur}

1. Linehan MM. Cognitive-behavioral treatment of borderline personality disorder. New York, NY: Guilford Press, 1993.

2. Linehan MM. Skills training manual for treating borderline personality disorder. New York, NY. Guilford Press, 1993. 